\title{
ORAL HEALTH CONDITIONS AND SELF-REPORTED PRESENCE OF PAIN IN ROWERS: AN EPIDEMIOLOGY STUDY
}

\author{
CONDIÇÕES DE SAÚDE BUCAL EAUTORRELATO DE DOR EM REMADORES: UM ESTUDO EPIDEMIOLÓGICO
}

ORTGINAL ARTICLE ARTIGO ORIGINAL Artículo Original

\author{
CONDICIONES DE SALUD BUCODENTAL Y PRESENCIA DE DOLOR AUTODECLARADO EN REMEROS: UN \\ ESTUDIOEPIDEMIOLÓGICO
}

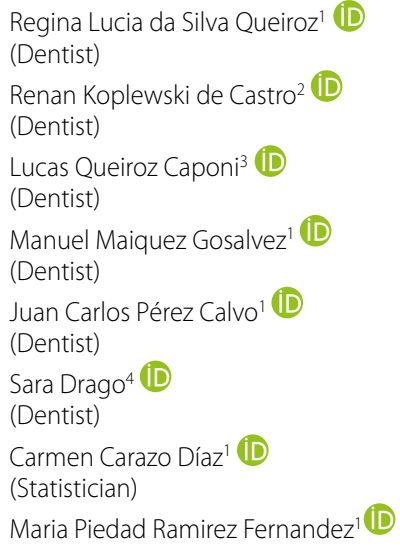

1. Universidad Católica de Murcia UCAM, School of Health Sciences, Murcia, Spain.

2. Independent Researcher,

São Paulo, SP, Brazil.

3. Universitat Internacional de Catalunya UIC, School of Dentistry, Department of Restoration and Esthetics, Barcelona, Spain. 4. Università di Genova, School of Dentistry, Department of Orthodontics, Genoa, Liguria, Italy.

\section{Correspondence}

Lucas Queiroz Caponi

Carrer Josep Trueta, s/n (Hospital Universitari General de Catalunya) 08195 Sant Cugat del Vallés, Barcelona, Spain

I.queirozcaponi@uic.es

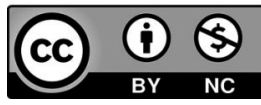

\begin{abstract}
Introduction: Rowers are especially prone to oral health problems due to the massive consumption of supplements and isotonic drinks that lead eating disorders, due to the need for weight control, and to the development of teeth clenching caused by the constant activation of the chewing muscles during sports activity. Objective: To evaluate the oral health status of a group of Brazilian rowers and to identify the main risk factors influencing their oral health. Methods: One hundred and twenty rowers ( 84 men and 36 women) with an age of $24.16 \pm 5.74$ years participated in this study; an average height of $1.79 \pm 0.09 \mathrm{~cm}$ and body mass of $75.02 \pm 11.64 \mathrm{~kg}$ were detected by means of a questionnaire focused on the main factors that influence the deterioration in athletes' oral health. Results: The dental results revealed a significant number of rowers with the oral breathing pattern (46.7\%), malocclusion (65.8\%), bruxism (33.3\%) and noise and/or pain in the TMJ (temporomandibular joint) (20.8\%). The use of supplements and isotonic drinks (48.3\%) and the incidence of bleeding gums (30.83\%) were also found. Conclusion: The results show the importance of making rowers aware of the relevance of oral health and the need for prevention systems, ideally including sports dentistry specialists within the sports medicine departments of rowing clubs. Level of evidence Il; Retrospective study.
\end{abstract}

Keywords: Oral heath; Athletes; Sports medicine; Epidemiology.

\section{RESUMO}

Introdução: Os remadores são particularmente propensos a problemas de saúde oral devido ao uso generalizado de suplementos e isotônicos, tendência a distúrbios alimentares pela exigência do controle de peso e ao cerramento dos dentes causado pela ativação constante dos músculos mastigatórios durante a atividade esportiva. Objetivo: Avaliar os distúrbios orais dos remadores brasileiros e identificar os principais fatores de risco de saúde bucal desses atletas. Métodos: Participaram deste estudo 120 remadores (84 homens e 36 mulheres) com idade de 24,16 $\pm 5,74$ anos, estatura de 1,79 $\pm 0,09 \mathrm{~cm}$ e massa corporal de 75,02 $\pm 11,64 \mathrm{~kg}$, que foram avaliados com um questionário que investigou os principais problemas de comprometimento da saúde oral dos atletas. Resultados: Os resultados odontológicos revelaram um número significativo de remadores com padrão respiratório oral (46,7\%), com histórico de maloclusão (65,8\%), com parafunção oclusal de bruxismo (33,3\%) e com ruído e/ou dor na ATM (articulação temporomandibular) (20,8\%). O uso de suplementos e isotônicos (48,3\%) e a incidência de sangramento gengival (30,83\%) também são achados relevantes. Conclusão: Os resultados obtidos mostram a importância de conscientizar essa categoria esportiva sobre a relevância da saúde oral e de estabelecer sistemas de prevenção, de preferência, com a inclusão de um especialista em odontologia do esporte no departamento de medicina esportiva dos clubes de remo. Nível de evidência ll; Estudo retrospectivo.

Descritores: Saúde bucal; Atletas; Medicina do esporte; Epidemiologia.

\section{RESUMEN}

Introducción: Los remeros son especialmente propensos a sufrir problemas de salud bucodental debido al uso masivo de suplementos e isotónicos, con tendencia a trastornos alimentarios por la exigencia de control de peso y el apretamiento dental, por la constante activación de los músculos masticatorios durante la actividad deportiva. Objetivo: Evaluar el estado bucal de un grupo de remeros brasileños e identificar los principales factores de riesgo para la salud bucal de estos deportistas. Material y método: En este estudio participaron 120 remeros $(84$ hombres y 36 mujeres) con una edad de 24,16 \pm 5,74 años; una altura de 1,79 $\pm 0,09$ cm y una masa corporal de 75,02 \pm $11,64 \mathrm{~kg}$, por medio de un cuestionario que indagó sobre los principales problemas de la salud bucodental de los deportistas. Resultados: Los resultados relativos al área dental revelaron un número significativo de remeros con patrón de respiración oral (46,7\%), con historia de maloclusión (65,8\%), con parafunción de bruxismo (33,3\%) y con ruido y/o dolor de la ATM (articulación temporomandibular) (20,8\%). El uso de suplementos e isotónicos (48,3\%) y la incidencia de sangrado gingival (30,83\%) son también datos relevantes encontrados. Conclusión: Los 
resultados obtenidos muestran la importancia de concientizar a esta categoría deportiva sobre la relevancia de la salud bucodental y establecer sistemas de prevención, preferiblemente con la inclusión de un especialista en odontología deportiva en el departamento de medicina deportiva de los clubes de remo. Nivel de evidencia II;

\section{Estudio retrospectivo.}

Descriptores: Salud bucal; Atletas; Medicina deportiva; Epidemiología.

\section{INTRODUCTION}

Athletes' oral health has been the object of research and concerns in the world of sport and various studies have shown that a large number of athletes are exposed to risks that impair their performance. There is a general consensus regarding the main factors that threaten oral health. These include dental caries, periodontal disease, erosion and pericoronitis, problems that can usually be prevented and avoided. ${ }^{1-3}$ Dental traumas and malocclusions also place the athletes' occlusal balance at risk, and consequently, their sporting performance. Other important factors are dehydration, immunosuppression induced by physical exercise, and a lack of information and preventive methods. ${ }^{4}$ The specific need for nutrition and hydration during sports practice leads to excessive intake of carbohydrate gels and isotonics, which contributes to the high incidence of oral diseases and has a negative impact on the quality of life of these athletes. ${ }^{5}$ Eating disorders are particularly prevalent among athletes of sports where control of body weight is necessary, such as boxing, gymnastics, horse riding, long distance racing and rowing. ${ }^{6-7}$

Preventive measures such as the use of fluoride toothpaste, guidelines on oral hygiene techniques, individual mouth protectors and adequate nutritional supplements are among the main recommendations. Providing information for coaches and athletes, implementing a prevention system, and demonstrating the clear importance of Sports Dentistry in the context of health are other measures that could help resolve this serious problem. ${ }^{8,9}$

The objective of this work is to evaluate the oral health of elite rowers of the Brazilian Rowing Confederation and to raise awareness of the importance of these measures in these athletes' performance. While conducting this study, no other epidemiological studies on oral health in rowers were found.

\section{MATERIAL AND METHODS}

This study was carried out from June to December 2019, in the cities of Rio de Janeiro and Sao Paulo, Brazil. The subjects were 120 rowing athletes (84 men and 36 women) with an average age of 24.11 years and average time practicing the sport of 7.64 years. All the athletes were members of twelve clubs affiliated with the Brazilian Rowing Confederation. The athletes rowed for an average 25 hours a week.

The inclusion criteria were age between 18 and 38 years, the presence of at least 28 natural teeth in occlusion, excluding extractions for orthodontic treatment, minimum rowing experience of 12 months, and a minimum of 10 hours of weekly activity. Athletes with cardiovascular and neurological diseases, diabetes, pregnant women and athletes without dental elements were excluded from the study.

The rowing clubs were contacted beforehand by sending a letter of invitation requesting the participation of the athletes in this research.

The questionnaire was applied at the headquarters of each rowing club, explaining, in advance, the type of research performed and obtaining the signed consent of each athlete.

The questionnaire was conducted in Portuguese and was answered anonymously. It contained 21 objective questions about the athletes' characteristics, clinical anamnesis, dental anamnesis, and sports practice, aimed at evaluating some oral health parameters.
The study was carried out in accordance with the Code of Professional Ethics of Universidad Católica de San Antonio de Murcia, Spain, and approved by the Ethics Committee on $7^{\text {th }}$ June, 2019, under code CE061909. The participating athletes were informed, in advance, about the procedures to be performed in each phase of the study and signed an Informed Consent Form drawn up for this purpose, according to the updated Helsinki Declaration.

\section{Statistical analysis}

The data were collected, tabulated, analyzed and processed using the statistical software R (version 4.0.2, R Foundation for Statistical Computing, Vienna). In the descriptive analysis, quantitative variables are summarized with mean, standard deviation, quartiles and amplitude, and qualitative variables with frequency distributions. For the analysis of the quantitative variables by sex, the means are compared using the $T$ test and for the analysis of qualitative variables, the proportions were compared using Fisher's test. Similarly, for the analysis of quantitative and qualitative variables as a function of the oral health variables (gingival bleeding, bruxism, orthodontic, pain in TMJ) and with laterality preference when chewing, the $T$ test and Fisher's test were used, respectively.

In the hypothesis tests developed in this study, a significance level of $5 \%$ is considered, i.e., the differences are established as significant when the $p$ value is less than or equal to 0.05 .

\section{RESULT}

We evaluated 120 rowers (84 men and 36 women).

The average age of the athletes was 24.16 years $(S D=5.74)$, the mean weight was $64.36 \mathrm{~kg}$ for the females $(S D=6.90)$ and $79.57 \mathrm{~kg}$ for the males $(S D=10.12)$. The mean height of the male rowers was 183 $\mathrm{cm}(S D=0.07)$ and that of the female rowers was $170 \mathrm{~cm}(S D=0.07)$, and the BMI was 23.13 (SD = 2.13). The athletes who took part in the study rowed for an average of 24.95 hours a week $(S D=7.96)$ and had been training for an average of 7.66 years $(S D=5.27)$. The detailed data are shown in Table 1.

Table 1. Demographic and rowing practice characteristics in whole population $(\mathrm{N}=120)$. Results are expressed as Mean \pm Standard Deviation or Frequency (percentage of subjects).

\begin{tabular}{c|c}
\hline & Total \\
\hline $\mathrm{N}$ & 120 \\
\hline Age & $24.16 \pm 5.74$ \\
\hline Height $(\mathrm{cm})$ & $179 \pm 9$ \\
\hline Weight $(\mathrm{kg})$ & $75.02 \pm 11.64$ \\
\hline BMl & $23.13 \pm 2.13$ \\
\hline Weekly average rowing (hours) & $7.66 \pm 5.27$ \\
\hline Side of Rowing & $24.95 \pm 7.96$ \\
\hline Right & $38(31.7)$ \\
\hline Left & $38(31.7)$ \\
\hline Two & $44(36.7)$ \\
\hline
\end{tabular}


The dental data, shown in Table 2, revealed that $48.3 \%$ of the 120 athletes evaluated used isotonic drinks and sports supplements and $30.8 \%$ had problems with bleeding gums. Meanwhile, 33.3\% reported a parafunction of bruxism, $46.7 \%$ had an oral or mixed breathing pattern (regardless of athletic gesture) and 65.8\%, i.e., 79 athletes, had a dental history, with the use of a fixed orthodontic device. No statistically significant differences were found between male and female athletes regarding dental data.

The data on pain are shown in Table 3, revealing that $65.5 \%$ of athletes reported having experienced pain due to sports activities. The most affected areas were: the back (46.2\% of the athletes); knees (27.7\%) and neck (13.4\%). Some athletes reported pain in different areas of the body at the same time. Women were more affected than men when it comes to pain in one or both feet $(p=0.029)$.

Table 2. Dental related habits in whole population $(N=120)$. Results are expressed as Frequency (percentage of subjects).

\begin{tabular}{c|c}
\hline & Total \\
\hline$N$ & 120 \\
\hline Sport Supplements & $58(48.3)$ \\
\hline Bleeding Gums & $37(30.8)$ \\
\hline Bruxism & $40(33.3)$ \\
\hline Oral Breathing & $56(46.7)$ \\
\hline Orthodontic History & $79(65.8)$ \\
\hline Noise or pain in the TMJ & $25(20.8)$ \\
\hline Right Side Chewing & $77(64.2)$ \\
\hline Left Side Chewing & $43(35.8)$ \\
\hline
\end{tabular}

Table 3. Pain related characteristics in whole population $(N=120)$. Results are expressed as Frequency (percentage of subjects).

\begin{tabular}{c|c}
\hline & Total \\
\hline$N$ & 120 \\
\hline Generalized pain & $78(65.5)$ \\
\hline Neck & $16(13.4)$ \\
\hline Spine & $55(46.2)$ \\
\hline Knee & $33(27.7)$ \\
\hline Shoulder & $15(12.6)$ \\
\hline Foot & $5(4.2)$ \\
\hline Hands & $5(4.2)$ \\
\hline
\end{tabular}

\section{DISCUSSION}

In the evaluation of the data obtained in this research, we can conclude that the rowers who participated in this study presented better oral health than the average found in similar studies, among participants of other types of sport. ${ }^{10,11}$ The high number of rowers with a dental history (65.8\%) suggests that these athletes were given guidance in the past and that they paid close attention to their oral health. However, the stressful pace of training they are submitted to, the possibility of developing parafunction as bruxism (in the case of 33.3\%), the high incidence of reported oral breathing (46.7\%) and dietary habits and the use of isotonic drinks and supplements (48.3\%) require accurate and specific control of these athletes.

The frequent teeth grinding, typical of some athletic gestures, may contribute to the appearance of temporomandibular disorders (TMD). Among the rowers researched, signs of noise and/or pain were found in $20.83 \%$, which is below the average found in studies performed with athletes of other sports. ${ }^{11}$

Considering the gum bleeding reported (30.83\%) as a sign of gum inflammation, these data obtained are lower than the average for similar studies performed in other sports that considered gingivitis as a parameter of oral health impairment. ${ }^{12,13}$ In a recent epidemiological study of patients from a university center in Brazil, the medical records of 2821 patients were evaluated and periodontal disease was identified in $71 \%$ of them. Evaluating the typology of the pathology, $79 \%$ was found to be gingivitis. The authors state that gingivitis has become the most prevalent periodontal disease today. ${ }^{12}$

These data coincide with a study performed by Needleman et al. ${ }^{13}$ in elite athletes who participated in the 2012 Olympic Games. After examining 278 athletes from 25 different sports, the result showed that $76 \%$ suffered from gingivitis. The authors concluded that the oral health of these athletes was deficient and that there was a negative impact on the athletes' well-being, training and performance.

Some authors state that the high rate of gum bleeding observed in their studies (96.5\%) confirms the theory that gingivitis is universal in some populations and highlights the importance of a program aimed at preventing this type of pathology. ${ }^{14}$

On the other hand, although bleeding can be considered a sign of gum inflammation, Trombelli et. state that self-assessment of bleeding is not sufficient to confirm a diagnosis of gingivitis. ${ }^{15}$

The use of carbohydrate supplements in the form of a drink, bar or gel, is associated with athletes' performance. ${ }^{16} \mathrm{~A}$ relevant figure found in this study was the number of athletes (48.3\%) who reported the consumption of sport drinks, gels and supplements, corroborating previous studies. ${ }^{17,18}$ The use of these substances has been linked, by several researchers, with the development of dental erosion, a type of change caused by a chemical process (non-bacterial) and that leads to an irreversible loss of the dental structure. It is a problem to which athletes are particularly subjected, due to the higher exposure to risk factors. ${ }^{13,19}$

Another important fact was the number of athletes who reported an oral breathing pattern (46.7\%), regardless of the athletic movement performed. Analyzed simultaneously with the high number of dental histories among these athletes, a reason may be found for this surprising figure, enabling it to be better understood.

Breathing is the most important physiological process and should develop an effective action during sports activity. Oral breathing prevents optimal performance in the athlete and is a topic that has been widely researched in the world of sports. ${ }^{20}$

The main causes of Oral Breathing Syndrome are mechanical obstruction of the upper airways, inflammatory diseases, muscle hypotonicity and congenital malformations, which prevent the normal passage of air through the nose. Some studies associate this syndrome with significant changes in body posture, with anteriorization of the head and shoulders, highlighting the importance of multidisciplinary therapy. ${ }^{21}$

The high number of athletes with dental history (65.8\%) who received treatment in the past proved to be an extremely positive figure in the population of rowers studied. The study suggests that these athletes had adequate dental information and were well advised on how to restore their oral health.

Dental occlusion can influence muscle tone both in chewing and postural balance 22 and malocclusion can be a factor that reduces athletes' performance. This argument was investigated in a recent study that demonstrated the negative impact of occlusal interference in young elite rowers. ${ }^{23}$ The authors of that study inserted devices that interfered with the occlusion of these athletes, simulating malocclusions. Based on the results, the authors suggest that dental occlusion tests should be performed regularly and that when detected, malocclusions should be treated to improve sports performance.

A very significant figure was the number of athletes who reported diurnal bruxism (33.3\%). According to the guidelines of the International consensus on the assessment of Bruxism, 2013, it is "a repetitive masticatory muscle activity characterized by clenching or grinding of the 
teeth and/or bracing or thrusting of the mandible. ${ }^{24}$ Bruxism can occur during sleep (nocturnal bruxism) or when awake (diurnal bruxism) and different factors are associated with this muscle activity. ${ }^{25,26}$

Bruxism is often associated with physical and psychological stress during certain sports activities, such as climbing, crossfit and rowing. Previous studies on bruxism in athletes found a high incidence of cases $(59.8 \%)^{27}$ and recent studies carried out in elite athletes found a $51.1 \%$ prevalence of bruxism. ${ }^{58}$

In a study carried out in kayak and canoe athletes, different forms of dental wear were observed. In the kayak athletes, symmetrical wear and symmetrical hypertrophy of the masseter muscles were observed. In the canoe athletes, the wear was prevalent on the active side of the rowing, with unilateral hypertrophy of the masseter muscles, coinciding with the active side of the rowing. The authors' conclusion was that elite athletes are predisposed to bruxism and that the consequent wear is distributed in a different way, depending to the sport practiced. ${ }^{29}$

Finally, the most relevant data found in the non-dental sphere refers to the low back pain reported in $45.8 \%$ of the athletes. This data is easily predictable, considering the position and the intense muscular and skeletal stress of the athletic movements. Similar studies confirm the high percentage of low back pain among rowers. ${ }^{30}$ This situation is often aggravated by the lack of time these athletes are given to recover from the physical stress.

\section{CONCLUSION}

Rowing is a sport that requires great physical preparation. Its technique is based on resistance, strength and muscle balance. The well-being and health of these athletes are fundamental to their performance, and oral health should be included in this context.

The results of this research suggest that greater care, and information about the risk factors that can compromise oral health and, consequently, performance, should be given to the rowers and to all those directly or indirectly involved with the health and well-being of athletes.

Understanding the risk factors and implementing prevention strategies is an important step toward reducing lesions of the oral cavity and increasing rowers'oral health. Only through epidemiological studies of each type of sport can we know the real risk factors for the oral health of athletes.

The presence of an Odontology Sports Specialist in the medical department of elite clubs is highly recommended.

\section{ACKNOWLEDGEMENTS}

The authors acknowledge the collaboration of the athletes, coaches and technicians of the rowing clubs who participated in this research, in particular the Technical Coordinator of the Brazilian Rowing Team, Marcelo Varriale.

This research did not receive external funding.

All authors declare no potential conflict of interest related to this article

AUTHORS' CONTRIBUTIONS: Each author made significant individual contributions to this manuscript. RQ, MG: study design; RQ, RK: recruitment of athletes, evaluation of athletes, instrumental examinations; RQ, LC: study design and writing; CD: statistical analysis; SD: data review and interpretation; MF, JC, MG: critical review of intellectual content and approval of the final version to be published. All authors reviewed and approved the final version of the article.

\section{REFERENCES}

1. Needleman I, Ashley P, Fine P, Haddad F, Loosemore M, de Medici A, et al. Oral health and elite sport performance. Br J Sports Med. 2015;49(1):3-6.

2. Ashley P, Di lorio A, Cole E, Tanday A, Needleman I. Oral health of elite athletes and association with performance: a systematic review. Br J Sports Med. 2015;49(1):14-9.

3. Gallagher J, Ashley P, Petrie A, Needleman I. Oral health and performance impacts in elite and professional athletes. Community Dent Oral Epidemiol. 2018;46(6):563-8.

4. Queiroz RLS, Ueda AJZ, Nogueira FN, Caponi LQ. Odontologia do esporte na adolescência. In:Vitalle MSS, Silva FC, Pereira AML, Weiler RME, Niskier RS, Schoen TH. Medicina do Adolescente - Fundamento e Prática. São Paulo, Rio de Janeiro: Editora Atheneu; 2019. p. 323-7.

5. Ceyhan D, Tolga, E. The Effects of Sports on Oral and Dental Health. Turk J Med Sci. 2020;3(2):1-5.

6. Walsh M, Crowell N, Merenstein D. Exploring Health Demographics of Female Collegiate Rowers. J Athl Train. 2020;55(6):636-643

7. De Bruin APK. Athletes with eating disorder symptomatology, a specific population with specific needs. Curr Opin Psychol. 2017;16:148-153.

8. Needleman, lan et al. Nutrition and oral health in sport: time for action. Br J Sports Med. 2018;52:1483-1484.

9. Pretty IA. High Fluoride Concentration Toothpastes for Children and Adolescents. Caries Res. 2016;50 Suppl 1:9-14.

10. D'Ercole S, Tieri M, Martinelli D, Tripodi D. The effect of swimming on oral health status: competitive versus non-competitive athletes. Int J Oral Sci. 2016;24(2):107-13.

11. Souza JJ, Grande RS, Bahls R, Santos FA. Evaluation of the oral health conditions of volleyball athletes. Rev Bras Med Esporte. 2020;26(3):239-42.

12. De Moura MC, Inacio IA, Cavalcante JL, Araújo LM. Prevalência da gengivite em pacientes atendidos em um centro universitário no interior do Ceará. Braz J Periodontol. 2020;30(03):43-48.

13. Needleman I, Ashley P, Petrie A, Fortune F, TurnerW, Jones J, et al. Oral health and impact on performance of athletes participating in the London 2012 Olympic Games: a cross-sectional study. Br J Sports Med. 2013;47(16):1054-8.

14. Haas AN, Prado R, Rios FS, Costa RD, Angst PD, Moura MD, Maltz M, Jardim JJ. Occurrence and predictors of gingivitis and supragingival calculus in a population of Brazilian adults. Braz Oral Res. 2019;33:e036.

15. Trombelli L, Farina R, Silva CO, Tatakis DN. Plaque-induced gingivitis: Case definition and diagnostic considerations. J Clin Parodontol. 2018;45:44-67.
16. Hills SP, Russell M. Carbohydrates for soccer: A focus on skilled actions and half-time practices. Nutrients. 2017;10(1):22.

17. Gallagher J et al. Oral health-related behaviours reported by elite and professional athletes. $\mathrm{Br}$ Dent J. 2019;227:276-280.

18. Al Saffan A et al. The effect of sports on oral health in Riyadh city: A cross-sectional study. Saudi J Dent Res. 2020:7(1):18-23.

19. Jena M, Satyarup D, Nagarajappa R, Dhar U, Dalai RP. Impact of Sports Drink on Oral Health. Indian J Public Health Res Dev. 2019;10(11):943-946.

20. Dallam GM, McClaran SR, Cox DG, Foust CP. Effect of nasal versus oral breathing on Vo2max and physiological economy in recreational runners following an extended period spent using nasally restricted breathing. Int J Sports Sci Coach. 2018;6(2):22-9.

21. Flanell M. The Athlete's Secret Ingredient: The Power of Nasal Breathing. EC Pul and Res Med. 2019;47(8):1-5.

22. Julià-Sánchez $S$ et al. The Influence of Dental Occlusion on Dynamic Balance and Muscular Tone. Front Physiol. 2020:10:1626.

23. Leroux E, Leroux S, Maton F, Ravalec X, Sorel O. Influence of dental occlusion on the athletic performance of young elite rowers: a pilot study. Clinics. 2018;73.

24. Lobbezoo F, Ahlberg J, Raphael KG, Wetselaar P, Glaros AG, Kato T, et al. International consensus on the assessment of bruxism: Report of a work in progress. J Oral Rehabil. 2018;45(11):837-44.

25. Kuhn M, Türp JC. Risk factors for bruxism. Swiss Dent J. 2018;128(2):118-24.

26. Wieckiewicz M, Winocur E. Sleep Bruxism - The Controversial Sleep Movement Activity. J Clin Med. 2020;9:880.

27. De la Parte Serna AC, De la Fuente FP, Monticelli F. Principales hábitos nocivos odontológicos para el alto rendimiento en deportes colectivos. Rev int deportes colect. 2020;42:72-82.

28. Zięba E, Byś A. Prevalence and risk factors for bruxism among climbers. J Phys Educ Sport 2019;9(9):400-405

29. Babiuc I, Minescu L, Tănase G, Bodnar T, Ionescu C, Dina Mn, et al. Clinical study on the incidence of bruxism throughout romanian high-performance athletes. Acta Med Transilvanica. 2019;24(3):103-106.

30. Gonzalez SL, Diaz AM, Plummer HA, Michener LA. Musculoskeletal screening to identify female collegiate rowers at risk for low back pain. J Athl Train. 2018;53(12):1173-80. 